\title{
The Covid-19 caesura and the post-pandemic future
}

\author{
Joelle M. Abi-Rached ${ }^{1}$
}

Accepted: 1 December 2020 / Published online: 3 February 2021

(C) The Author(s), under exclusive licence to Springer Nature Limited part of Springer Nature 2021

Books reviewed:

Attali, J. (2020) L'économie de la vie. Paris: Fayard.

Horton, R. (2020) The Covid-19 Catastrophe: What's Gone Wrong and How to Stop it Happening Again. London: Polity.

Morin, E. (2020) (with the collaboration of Abouessalam S.), Changeons de voie : Les leçons du coronavirus. Paris: Denoël.

Nancy, J-L. (2020) Un trop humain virus. Paris: Bayard.

Žižek, S. (2020) Pandemic!: Covid-19 Shakes the World. London: Polity.

In the wake of the World Health Organization (WHO) declaring a public-health emergency on January 30, 2020, countries around the world began to shut down, in order to combat Covid-19, an infectious disease caused by a novel and lethal coronavirus. Governments took over the national production of vital items, such as ventilators; they seized vital stocks of masks and confiscated hotels to lodge people who needed to isolate and quarantine away from their families; they allowed 'telemedicine' or telehealth services en masse as an attempt to decelerate the circulation of the virus; and "Zoom," a cloud-based communications technology, now widely used for conferences, meetings, and online education, became a household name in a matter of weeks. Amid global chaos and uncertainty, it became crystal clear that we had moved into unchartered territory and finally jumped into the twenty-first century. The world was suddenly facing old problems in new guises: a political crisis (national, ideological as well as geopolitical), an economic crisis of unprecedented proportion since the Second World War, an ecological crisis, and above all, perhaps, a crisis of imagination and thought.

Joelle M. Abi-Rached

joelle.abirached@sciencespo.fr

1 Sciences Po, Paris, France

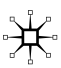


The period of lockdown (also called 'confinement') then relaxation of restrictive and stringent measures (aka 'de-confinement') saw a deluge of papers, books, and publications on the social, economic, political, and indeed moral repercussions of Covid-19. A slew of experts and intellectuals have written about the brave new world' we have entered and what a post-Covid world would look like. In this essay, I review a selection of these books that have appeared in English and French and which, I think, allow for a rich post-mortem of some of the salient intellectual conversations that have taken place. Though incomplete and rushed, these books chart some of the emerging key issues and questions we will be grappling with for a while before the tempest abates.

\section{A crisis of imagination}

Perhaps the best illustration of the crisis of imagination is the way in which some commentators, such as the Italian philosopher Georgio Agamben (2020), have been alarmist at every measure taken to curb the transmission of the virus, parroting outof-date arguments about the hegemony of the 'state of exception,'-which entailed in this particular sanitary context, imposing restrictions on movement and the suspension of daily activities. In his short meditation on Covid-19 Un trop humain virus (An all-too-human virus), the philosopher, Jean-Luc Nancy (2020), argues that such conflation of different kinds of states of emergencies with the "state of exception" summons, unhelpfully (at least in the context of democracies), "the ghost of Carl Schmitt" (the German conservative jurist and Nazi supporter from whom the concept of the state of exception-central to Agamben's philosophy—is taken) (p. 15). Nancy (2020) does not hide his distaste for such hasty amalgamation: "the virus thus spreads the discourse of ostentatious bravado" (p. 15). The title of his book is of course an allusion to Nietzsche's Human, All Too Human. Nancy (2020) argues that diseases, which were once "exogenous" (thought to be the product of divine anger and punishment) are today "endogenous" (the product of our modern ways of living) (pp. 17-18). Hence, he suggests, the virus is "all too human." And there is nothing extraordinary — nothing exceptional, we might say-either in people's reactions (for example, fear) nor in the way in which governments have reacted to stop the destructive path of the virus.

Even Slavoj Žižek (2020), the idiosyncratic philosopher-political theorist, found Agamben's response inappropriate. In Pandemic!, which appeared with remarkable speed, he writes: "Agamben's reaction is just the extreme form of a widespread Leftist stance of reading the "exaggerated panic" (Žižek 2020, p. 75). While Žižek (2020) provides a strong rebuttal to Agamben's reaction, his critique extends to what he sees as both extremes of the political/ideological spectrum: "Both Alt-Right and [what he calls] Fake-Left refuse to accept the full reality of the epidemic, each watering it down in an exercise of social-constructivist reduction, i.e., denouncing it on behalf of its social meaning" (p. 76).

All the authors reviewed here agree that the new virus has, however, revealed fault lines in our societies as well as new possibilities. Thus, for Žižek (2020), the 
threat of viral infection has given "a tremendous boost to new forms of local and global solidarity," and at the same time it has "made more starkly clear the need for control over power" (p. 75). In other words, it was up to the people to judge a government's performance at controlling the epidemic; thus the push for making governments accountable (Lazarus et al., 2020) in order to prevent what Nancy (2020) calls "the suspicion of despotic arbitrariness" (p. 42). Even if mask wearing is mandatory in many areas, it was up to people to wear them in a show of solidarity toward the most vulnerable-cancer patients, the elderly, those with pre-existing medical conditions - and who were at increased risk of dying from the novel coronavirus. Agamben's stance "misses the paradox," writes Žižek (2020), "not to shake hands and isolate when needed IS today's form of solidarity" (p. 77). In other words, we need to reimagine solidarity, which includes "corporal distance" (or physical distance) as a new civic manner to show respect to others, especially toward the most vulnerable in society (Žižek 2020, p. 88). As Žižek (2020) further writes, it was up to Western governments to show that virus containment could be managed through democratic and transparent means (p. 76) and not through a perpetual and dystopian 'state of exception.'

One might also add that the new pandemic has given-perhaps for the first time-more precedence to health over the economy or even politics, so as to, inter alia, avert the collapse of health care systems. It will suffice to recall that the socalled Hong Kong flu, also known as the 1968 flu pandemic, killed over one million people globally without causing any economic crisis simply because no such radical lockdowns were implemented. In France, where more than 30,000 people died from the Hong Kong flu, no one even seems to remember it (Podcast, 2020). Thus the consequence of this precedent-valuing health or life over the economy during this pandemic - has been an unprecedented economic recession. We are in fact witnessing an interesting shift in the way in which life is valued. Not only do we value more biological or biographical life, as Didier Fassin (2018) argued in his book La vie (Life), but we seem to value certain lives over others; the immediate lives at risk from Covid-19, for example, rather than the future lives at risk, i.e., the countless people who have stopped going to the doctor to do their annual screening tests or undertaking other preventive tests for fear of catching the virus. And perhaps more interestingly, we seem now to value more social capital (i.e., the accumulated stock of professional skills) over immediate cash. We have seen how richer economies that can afford to be more in debt have spent about ten times more (in terms of share of GDP) than lower income countries to offset the socioeconomic impact of the pandemic by saving their institutions, industries, factories, and the engines of their economy (Gaspar et al., 2020).

Yet even if health, and therefore life, has taken precedence over politics, the concept of 'biopolitics' (introduced by Michel Foucault in the 1970s to describe the way in which governments govern their populations) (Foucault, 2004) seems to have been deeply challenged by the current sanitary crisis. Both life and politics appear to be equally ambivalent, complex, and elusive. For Nancy (2020), the concept of biopolitics has thus become "dubious" (p. 82) for there is no politics of life in the sense of a politics that is based on unambiguous techniques and technologies (pp. 18-19 and pp. 81-83). The Covid-19 pandemic has shown how scientific 
expertise is itself precarious and how a politics based on scientific expertise can be imperfect, sometimes even dangerous to health.

\section{Scientific expertise and governance}

In The Covid-19 Catastrophe, Richard Horton (2020), the energetic editor-in-chief since 1995 of the medical journal Lancet, turns exactly to the relationship between science, politics and governance, only cursorily addressed by Nancy (2020), by providing a scathing critique of the richest and most scientifically advanced countries' response to Covid-19. His verdict is clear: advanced countries have astoundingly failed in managing the Covid-19 pandemic and if they are to avoid repeating the same mistakes in the future, they ought to learn more about their blind spots and "cognitive biases" (Horton 2020, p. 84).

His book is at the same time a useful chronicle of the unfolding crisis, a critique of the policy response in many countries (more specifically the US and the UK), and a semi-sociological essay on the long-term implications of the pandemic. The 'semi' has to do with the fact that while Horton (2020) engages with key texts, which many readers of this journal are familiar with (Ulrich Beck's Risk Society, Didier Fassin's Life, Michel Foucault's Discipline and Punish), the engagement can be amusing from a social science perspective; Horton sounds at time like an earnest student who discovers for the first time disturbing 'truths' about the politics of life, health, and medicine.

But I would also like to argue that this phenomenon of a figure from the medical world picking and choosing from a vast and rich literature is symptomatic of a bigger problem at the heart of the governance crisis that Horton so well describes. If, as Horton (2020) writes, "we need to foster better and more informed conversations (and criticisms) about our present and future, about the kinds of people we want to be, about the kind of society we wish to inhabit, and about what we owe to one another" (p. 114), then clearly we need to include more relevant people to this conversation. Social scientists, especially anthropologists, sociologists, ethicists, and historians who work on the politics and socioeconomic repercussions of health and life, are invisible on the policy stage. Scholars who work on the history of public health, the socioeconomic and moral repercussions of epidemics, including the stigmatization, xenophobia and other social prejudices that emerge in times of crises, and more broadly speaking scholars who work on the politics of bodies and numbers have so much to contribute in this complex crisis. I would even argue more forcefully that they should play a more active role in the decision-making processes of so many of these advanced neoliberal democracies in crisis. While in France there is one sociologist and one anthropologist among the eleven members of the scientific council on Covid-19, there are none on the UK's SAGE committee for Covid-19.

Horton asks pertinent questions about the tense and vexed relationship between scientific expertise and governance. If expertise is somewhat taken for granted in the other books reviewed in this essay, Horton (2020) stands out in debunking the concept of 'expertise' at least in how dangerous it can be when it becomes subservient to politics. But the failures in governance are multiple and include failure not 
only of technical advice and of acting upon scientific expertise, but also of political leadership and communication. "The response of governments to COVID-19," Horton (2020) writes, "represents the greatest political failure of Western democracies since the Second World War" (p. 84). An additional failure one might add is that of prevention. In leaked confidential data published by Le Monde, France appeared to have had at the beginning of the so-called first wave of the pandemic very low stocks of not only masks (the target of much criticism) but, more worryingly, of antivirals and antibiotics (Hecketsweiler and de Royer, 2020). Horton (2020) speaks of "state negligence" (p. 86) to refer to this incomprehensible lack of government preparedness and failure to prevent unnecessary deaths, especially given the repeated warnings by the scientific community about the evidence coming from Wuhan, China, where the novel coronavirus first emerged.

Yet Horton fails to address properly the question of prevention, which is essential in any debate about preparedness for the next pandemic. Take the case of the former French minister of health Roselyne Bachelot who, in 2009, during the H1N1 pandemic, ordered 94 million doses of vaccines and a stock of almost 2 billion masks. The predicted catastrophic numbers, however, did not manifest: France registered a few hundred deaths and barely 6 million people were vaccinated; 662 million euros were spent in total and fifty million doses of vaccine were returned to laboratories (Archyde, 2020). Bachelot was admonished and removed from her position (under the pretext of a government reshuffling). Ten years later, during the first wave of the Covid-19 pandemic, France had an acute shortage of masks exposing its healthcare workforce to unacceptable risks. Bachelot, it turns out, was right to think about prevention and precautionary measures. But why isn't prevention valued in democracies? Why is risk taking in stock exchanges and in bank loans accepted but risk taking in stocking medical supplies not? All the authors reviewed in this essay fail to address these crucial questions.

While Horton (2020) talks about the collusion of experts with politicians, he does not mention the troubling role of money in the production of scientific knowledge. At the heart of the controversy around the unorthodox microbiologist Didier Raoult-hailed as a hero by the people of Marseille (where he works and heads an infectious disease research institute) and rejected as pariah by many of his peers in France and abroad - not only is his questionable promotion of the antimalarial drug hydroxychloroquine for Covid-19 (Sayare, 2020) but also his sustained denouncement of the ubiquitous conflicts of interest in the scientific community. It will suffice to mention Yazdan Yazdanpanah (head of the infectious diseases department at the Bichat Hospital in Paris) who is a member of two scientific committees created by the French president to oversee the Covid-19 crisis as well as a member of the steering committee for the major French-sponsored clinical trial, 'Discovery,' to decide on the best medical treatment for Covid-19 (Mucchielli, 2020). Yazdanpanah's links with Gilead Sciences - the pharmaceutical giant behind one of the potential treatments for Covid-19 (Remdesivir) that turned out to be a fiasco-are numerous (Mucchielli, 2020). But Yazdanpanah is not the only one with such disconcerting conflicts of interests in a position of power (Roussel and Raoult, 2020) that may have misled the European Commission into wasting $€ 1$ bn on such a useless yet expensive drug (Mancini et al., 2020). 
Lancet has been at the forefront of scientific publications coming out in real time as the crisis unfolded and lockdowns were put in place. However, the prestigious medical journal was also caught in a major controversy that Horton (2020) omits from his book. Yet, this is a scandal that deserves to be mentioned and studied. Had Horton (2020) also consulted the long literature on the politics of Big Pharma, he may have found it relevant to comment on a scandal that involved his journal or at least mention the controversy within the framework of the poor governance that he so thoroughly and passionately decries. The scandal erupted when investigative journalists and medical professionals found that there were major concerns with a study that had concluded that hydroxychloroquine (a drug that has caused much controversy in this pandemic) was linked to a higher mortality among Covid-19 patients, leading the WHO to stop several clinical trials (Davey, 2020). The study relied on data from a small company called Surgisphere, which uses big data, artificial intelligence, and machine learning to analyze information pulled from many anonymized sources. It turned out, however, that Surgisphere's database was an obscure and impenetrable "black box," in Latourian parlance, reflecting the paradoxical process of increasing obscurantism with increasing technology (Latour 1999, p. 304). Having failed to audit the data, The Lancet had to retract the study.

Horton (2020) seems acutely aware of the wide-ranging trail of destruction that Covid-19 will leave, "on governance, on publics, on medicine and on science" (pp. 121-122). Yet he refrains from sharing with us his thoughts on how the pandemic will reshape the industry of scientific publication and research. Never before has there been such a flood of information, in specific of scientific publications, as a health crisis unfolded in real time; and never before have these scientific publications received so much scrutiny from the scientific community as well as from the broader 'lay' public.

\section{Covid-19 as a 'stress test'}

One of the key challenges for controlling this pandemic in the age of social media is the accompanying 'infodemic.' In 2003, the journalist and political scientist David Rothkopf coined the term in a Washington Post column to describe the flow of disinformation on social media regarding the SARS (Severe Acute Respiratory Syndrome) outbreak. ${ }^{1}$ In his own use of 'infodemic,' Horton (2020) not only means fake news and conspiracy theories fuelled by Covid-19 but, interestingly, also includes efforts by governments "to rewrite the narrative" of this pandemic (p. 92). His naivety here is rather alarming. For instance, he is surprised to note the insidious ways and forms of state control. He writes: "just as there has been a struggle to contain the outbreak, so there is a struggle to control the way the public views government management of the outbreak" (Horton 2020, p. 92).

\footnotetext{
1 Rothkopf, D. J. (2003) When the buzz bites back. Washington Post, 11 May: https://www.washington post.com/archive/opinions/2003/05/11/when-the-buzz-bites-back/bc8cd84f-cab6-4648-bf58-0277261 af6 $\mathrm{cd} /$.
} 
Later he continues, "...governments have been surprised by the compliance of their usually dissenting and awkward publics. They-we-have willingly adhered to government demands to stay home under lockdown. Perhaps we will be equally docile when it comes to oversight of our daily lives" (Horton 2020, p. 105). Horton (2020) also seems to re-discover 'biopolitics' and 'biological citizenship' (a concept coined in 2002 by anthropologist Adriana Petryna in her ethnography of the aftermath of the Chernobyl disaster $)^{2}$ since he fails to engage with the long and rich literature related to what he calls "biopolitical citizens" (p. 109).

For someone who has quoted Foucault at length in his short book, including the role of the panopticon illustrated by the International Health Regulations (an agreement between all WHO Member States that work together for 'global health security'), Horton (2020) should know perfectly well that governmental manoeuvres to rewrite the narrative of a public health crisis, as well as other intrusive tools deployed to track populations, form the basis of Foucault's disciplinary society. Nothing is either new or surprising here. Indeed, there is a long literature on how governments have historically controlled perceptions of diseases and their management of epidemics and the history of public health is replete with well-known discussions on authoritarianism, control, and surveillance. But to answer briefly Horton's (2020) central concern, yes, there is something sinister about this Orwellian scenario of the surveillance state (p. 107). However, although Covid apps and other artificial intelligence-based applications to track infected individuals and identify contacts have been found to be intrusive and problematic, especially when used in authoritarian settings, this is still only one tentacle of the much bigger and invasive surveillance apparatus. It would be naïve to think otherwise.

"Covid-19 is not a crisis about health. It is something much worse," writes Horton (2020, p. 95). Indeed, for many of us versed in the history of medicine and public health, this is not news. Epidemics, historically speaking, are not a crisis about health as much as a crisis about governance, a test about societal values and cohesion, a reflection of the prevalent assumptions of the day as well as many dormant prejudices and invisible inequalities. Charles Rosenberg, the doyen of the history of medicine, recently said during a virtual conference of the American Association for the History of Medicine, that pandemics are a "stress test" about what hold societies together (Caomhánach and Catlin, 2020). A few days later, in an interview for the French newspaper Libération, Bruno Latour used the term "crash test" (Sardier, 2020) to describe the impact of the Covid-19 pandemic on societies. Both meant exactly what Horton writes about, that pandemics test the resilience in a society, its cohesion, institutions, and values. "Covid-19 invites us, calls on us, requires us to rethink who we are and what we value" (Horton 2020, p. 64).

Horton further reminds his readers of the temptation to biologize disease. He writes: "we can view Covid-19 as a biological challenge to understand, treat and prevent. But we should also understand it as a biographical event in the lives of millions of people" (Horton 2020, p. 97). Again, though a truism for many who work

\footnotetext{
2 See Petryna, A. (2002) Life Exposed: Biological Citizens After Chernobyl. Princeton, NJ: Princeton University Press.
} 
on the sociology and anthropology of health or the history of medicine and public health, this is an important point to reiterate. Yes "it is our task to uncover the biographies of those who have lived and died with Covid-19. It is our task to resist the biologicalisation [sic.] of this disease and instead to insist on a social and political critique" (Horton 2020, p. 98). However, the history of this 'critique' is vast, and Horton (2020) fails to address it substantially. In particular, Horton (2020) misses a key issue, namely, the avalanche of statistics and 'big data,' as well as the reification of numbers in the press and the public discourse.

I have already alluded to The Lancet debacle with Surgisphere, a company that relies on artificial intelligence and big data to analyze medical records and on which at least two scientific papers (now retracted, the other one was published in the New England Journal of Medicine) have drawn to make broader conclusions about Covid-19. Surgisphere, however, is one illustration among many others of how big data has been used during this pandemic. The "fetishization of numbers" as Ian Hacking (1982) calls it goes back to the seventeenth century with the emergence of probability and statistical reasoning. But what is perhaps new in this history is the mutation in the scale and scope of big data, the deluge of articles in the public sphere, as well as in scientific articles to make claims and gain insights into this pandemic. One should remember that while statistical analysis is a powerful and useful tool, it can also conceal so much of the reality of social life as well as the biases that go into its own 'construction,' and in the context of Covid-19, into the production of epidemiological variables as such. There is also a temptation to believe that data represent a pre-given 'reality' though many historians of science and sociologists of quantification have convincingly shown how these visualizing and schematic tools are simplistic and reductionist. They can help experts speculate and project trajectories and case scenarios but they capture reality at best imperfectly.

What all the authors reviewed in this essay miss mentioning is how data themselves are such fragile entities that require a reliable and rigorous organization. The journal Nature recently reported that the US is having "a coronavirus data crisis" in which "political meddling, disorganization and years of neglect of public-health data management mean the country is flying blind" (Maxmen, 2020). Of course, the US is not an exception, and many other countries around the world including the UK, have struggled either in consistently publishing data or updating the public about them. As Tim Harford (2020) reminds us, data require a scrupulously regulated and laborious infrastructure that needs money and relies heavily on trained, competent, and perhaps above all honest bureaucrats.

\section{Geopolitics}

In contrast to the other books reviewed in this essay that shed light on the new forms of local solidarities that the pandemic has rendered visible or made possible, Horton (2020) stresses "our [global] inability to cooperate, to coordinate and to act together" (p. 56). The US president (at the time of writing), Donald Trump, has accused China of lying about its numbers, concocting the novel coronavirus in a laboratory in Wuhan (where the outbreak first emerged), and intentionally exporting 
it. Trump repeatedly made these allegations even though a natural origin is still the most likely explanation and despite epidemiologists warning for years about a new pandemic that would most likely emerge from the bat population, precisely the source of the new virus (Cyranoski, 2020). The US has likewise accused the WHO of mishandling the pandemic by blindly trusting Chinese numbers and leaving countries to struggle on their own (Horton 2020, p. 103). In a show of defiance, the US even suspended its funding of the WHO accusing it of failing to promptly investigate China's Covid-19 outbreak and acting in a way that was perceived as "Chinacentric" (Horton 2020, p. 90).

Despite serious shortcomings in the WHO response and unanswered questions about what really took place in Wuhan, Horton (2020) is right in arguing that blaming either China or the WHO for the pandemic deflects blame from Western democracies for their own failings (p. 88). China's scientists did act decisively. Early warnings were promptly shared with the scientific community and yet Western governments failed to act on those warnings. While Horton (2020) panders perhaps too much to China's "acumen," innovation and "desire among its best minds to collaborate" (p. 124), Slavoj Žižek (2020) in contrast takes a markedly different view of the actions and attitudes of the Chinese state. "One can say that the whole functioning of the Chinese state apparatus runs against old Mao's motto 'Trust the people!'” he writes (Žižek 2020, p. 7). Both, nevertheless, agree that the central authority in Beijing felt profoundly threatened by these new challenges.

To this geopolitical dynamic, Žižek (2020) adds less obvious actors, like Russia and Turkey. He even has a name for these odd bedfellows, the "Putogan virus" (p. 32); a portmanteau for Russia's Putin and Turkey's Erdogan who have been-in Žižek's (2020) account—exploiting the global pandemic for political gains. Žižek (2020) paints in broad strokes to describe what he believes is a "perfect storm" gathering in Europe, a triple crisis that includes the epidemic crisis, the concomitant economic crisis, and the refugee crisis, which he implies is the main challenge facing Europe today. However, this usage of the metaphor of the "perfect storm" (p. 31) can be misleading if what is meant by it is a natural and unpredictable confluence of various factors (Brandt and Botelho, 2020).

Edgar Morin is more precise in his diagnosis. According to Morin (2020), the biggest test for Europe's project was the first wave of the pandemic when Italy and Spain's healthcare systems largely collapsed and it became clear that they would endure deeper economic recessions than other European countries. Although Germany's healthcare system is the most capacious in Europe, there was little enthusiasm to take in Italian or Spanish patients. China, on the other hand, sent in planeloads of ventilators, masks, and even whole medical teams to Italy and other countries severely affected by the pandemic before France or Germany even budged. Europe remains a precarious project—a "skeleton" (Morin 2020, p. 58)—for now, though the historic economic package that was put together may have saved it from immediate dissolution. Indeed, on July 21, 2020 the European Council, agreed on a $€ 750 \mathrm{bn}$ ( $\$ 858 \mathrm{bn})$ package to help countries' economies recover from the pandemic. The deal was hailed, perhaps somewhat optimistically, as a demonstration of the bloc members' "sense of solidarity needed to respond collectively to disasters, 
despite internal political splits and grumbling from some of the rich members that foot most of its bills" (Economist, 2020).

Nations becoming more inward-looking at a time when global solidarity is most needed is understandable, if worrisome. "If that is the path our world takes, there is no prospect for preventing the worst excesses of a future pandemic," Horton (2020) warns (p. 123). He fears we will become blasé, unmoved by the incompetence of governments, and their inward-looking patriotic sentiments. He worries that "fear will become a new organizing principle of society" (Horton 2020, p. 125). $\mathrm{He}$ also fears that the facts and lessons of the pandemic will be forgotten just as we forgot the lessons of the 2002-2004 SARS outbreak (Horton, p. 125). He wonders, toward the end of this short book, whether remembering the dead of this pandemic could remedy this collective amnesia (Horton 2020, p. 125). This exercise in what Paul Ricoeur (1999) calls an "ethic of memory" is interesting when relevant. Recently, while hiking in the south of France I came across the 'plague wall,' a $27 \mathrm{~km}$ wall built in 1720 to protect residents from the plague that struck Marseille. But today the wall lies there as an innocuous barrier, a manmade artifact. There is no biography of any of the 100,000 victims of the so-called 'great plague,' no lives to remember, only stones that may conjure up the claustrophobic prospect of the cordon sanitaire, of our vulnerability, and our mortality. Who among the two million (so far) Covid-19 victims shall we remember in such a porous world as this, with no physical wall one can point to as the border between the living and the dead?

Covid-19 has indeed profoundly "defined the beginning of a new epoch," as Horton (2020) writes (p. 127). Yet it remains to be seen what this new epoch will look like. Will people be more solitary or united? We are, after all, whether we like it or not, still interdependent social animals in a hyper-globalized world.

\section{A new form of capitalism}

Albert Camus (2002) ends his allegorical novel The Plague written in 1947 (La peste) with an unnerving reminder "that the plague bacillus never dies or vanishes entirely, that it can remain dormant for dozens of years in furniture or clothing, that it waits patiently in bedrooms, cellars, trunks, handkerchiefs and old papers, and that perhaps the day will come when, for the instruction or misfortune of mankind, the plague would rouse its rats and send them to die in some well-contended city" (pp. 237-8). In contemporary genetic parlance, the virus mutates and is resilient. We know for a fact that it will strike back again. The virus "will always be with us as a dark shadow posing a threat to our very survival, exploding when we least expect it" (Žižek 2020, p. 52).

And yet (Žižek continues) "one thing is sure: isolation alone, building new walls and further quarantines, will not do the job. Full unconditional solidarity and a globally coordinate response are needed, a new form of what was once called Communism. If we do not orient our efforts in this direction, then Wuhan today may well be typical of the city of our future" (Žižek 2020, p. 56). This new form of communism, Žižek (2020) argues, will rely on or acknowledge interdependence, and the necessity of global coordination and collaboration, because well, that is the only way our 
human species could survive. It is either "barbarism or some kind of invented Communism" (p. 70).

Barbarism came in different guises during this pandemic. One such instance is through the so-called herd immunity approach that the UK government had promulgated early on before backing away, and indeed denying that this was ever the policy (Horton 2020, p. 51). This policy of laissez faire would have encouraged more people to get infected by a poorly understood virus, deliberately allowing (rather than preventing) the deaths of countless people, while creating collective immunity. With a mortality of $1 \%$ for a population of some 66 million people, the UK would have had to sacrifice 400,000 people to reach the $60 \%$ threshold of collective immunity for this particular virus (Horton 2020, p. 51). And since we know that Covid-19 affects overwhelmingly the poorer, the more vulnerable, and the sicker, this approach was deliberately treating the less privileged people as if they were sickly cattle. This was a survival of the fittest strategy where the 'fittest' are not only healthier but also wealthier.

They were other such 'barbaric' behaviors during the pandemic. Žižek (2020) mentions the global outcry to Trump's announcement that he would pay $\$ 1$ bn to secure a vaccine for the coronavirus that was being produced by a German biopharmaceutical company exclusively for the US (p. 91). We could add other examples, such as how masks made in China and destined for France (then in the middle of the first wave) were snatched on the tarmac by US businessmen who were paying in cash (Willsher et al., 2020). There seems to be an obvious struggle now being played out on the global stage between "privatization/barbarism and collectivism/civilization" (Žižek 2020, p. 91).

However, the pandemic also made evident a new form of "communism," Žižek (2020) argues, "not a utopian Communist vision" but one "imposed by the necessities of bare survival" with liberal indeed neoliberal democracies taking over private production of key items such as masks or ventilators, a basic income being distributed to all adult citizens, and so on. This is the "alternate society" Žižek (2020, p. 113) argues for, even if impressionistically. He suggests that the responses of governments "have made us all communists now" in the sense of enabling "new forms of local and global solidarity" while "abandoning market mechanisms" to solve social problems and avoiding a "new barbarism" (Žižek 2020, p. 113).

This is where Nancy's (2020) reading of communism differs from Žižek's (2020). While it is true that Covid-19 has demonstrated the advantages of more collectivist societies in better mitigating the socioeconomic and health impacts of the virus, communism in Marxist parlance is more about self-realization (Nancy 2020, p. 23). From this perspective, it is noteworthy that the virus has brought us together paradoxically in a new form of communion. In our individual experiences of isolation and quarantine, of caring for a sick relative or simply living under lockdown, we have all shared one common experience: the threat of the virus. It is for this reason that some have even referred to the virus as the "communovirus" (Nancy 2020, p. 21).

However, what Žižek (2020) strikingly misses is that state interventions were quintessentially made in the name of capitalism. Without such interventions, economies would have collapsed. In contrast to real communism-if we may put it as 
such - the State in this pandemic became the market or a substitute for the market. In other words, what happened was a take-over by the State to save the market economy, or what was left of it. Remarkably, the European Union, for the first time since its inception, decided to share collectively the burden of borrowing at more than $3 \%$ deficit. This is a historic first. In sum, everybody became a socialist not for the sake of the survival of the species per se but to save capitalism from collapse. And this is why Nancy (2020) is more precise in his characterization of the pandemic. He believes that Covid-19 is the product of a globalized "techno-capitalism" (Nancy 2020 , p. 24) which, we might add, creates new problems and comes up with the solutions to fix them while profiteering from them, hence expanding capitalism even further. The Canadian social activist Naomi Klein (2008) has called this paradoxical behavior of capitalism, "disaster capitalism." Far from being an "antidote to disaster capitalism" as Žižek (2020) argues (p. 103), Covid-19 is its perfect illustration (Solis, 2020).

Capital is not going to disappear. If anything, it is mutating, taking new forms, and conquering new unexploited terrains. Žižek again does not seem to realize or at least grasp the significance that a new form of capitalism is emerging thanks to the pandemic, what Daniel Cohen has identified as "digital capitalism" (capitalism numérique) (Reverchon, 2020). Jacques Attali (2020), another French economist, outlines the characteristics of this new form of capitalism in his book L'économie de la vie (The economy of life). This new form of capitalism challenges the old infrastructure and physical sites of capitalism. We will have to "create together," Attali (2020, p. 131) tells us, new ways of organizing our modes of production. The pandemic has made "remote working" a reality, and the traditional "office" workspace too will have to be reimagined before it disappears (Attali 2020, pp. 138-140). We are far from the communist scenario imagined by Žižek (2020) where the laws of the market are suspended.

\section{The post-Covid future}

Edgar Morin (2020) is France's most eminent philosopher-sociologist known for his work on 'complex thought' (la pensée complexe). Having been himself almost stillborn because of the Spanish flu (Morin was born in 1921), his life is once again threatened by the new pandemic since he is part of a 'category at risk' (being a man and almost one-hundred-year-old!). Morin's book, more than the others in this essay, is about the future. He is both diagnostic and prescriptive. He examines the implications of the crisis for our survival as a species and the way in which we can forge new social contracts and new solidarities to change the course of history. Morin (2020) also diagnoses many ills laid bare by the Covid crisis beyond those identified by Horton and Žižek, and selects 15 "lessons" we should all reflect on more thoroughly, if we are to change the course of history: these are lessons about our lives; the human condition; the uncertainty of life; our relationship to death; our civilization; the awakening of solidarity; social inequality; the various strategies and responses across the world to manage the epidemic; the nature of the crisis; the relationship between science and medicine; the nature of intelligence; the deficiencies 
of political thought and action; the lethal dependence on the global economy; the crisis in Europe; and finally the crisis of the planet.

The pandemic crisis has exposed the fragile foundations of the neoliberal order and the precarious project of hyper-modernity, hyper-industrialism, and hyper-capitalism. On the one hand, the neoliberal order has disturbed the resilience of local economies, while, on the other hand, it has upset our symbiotic ecological relationship with other species given the destructive nature of frantic consumerism and globalization. Nancy shares Morin's analysis: "the current crisis marks the exasperation of our endless conquests in which we find ourselves entangled and bogged down to the point of being trapped" in vicious circles of emancipation and self-destruction (Nancy 2020, p. 43). Pandemics are becoming more common, increasingly harder to control, and more lethal. We live longer thanks to wealthier economies at the same time this longevity might be precarious given the growing threats of deadly epidemics on both lives and livelihoods. This is our Promethean tragedy.

Yet Morin (2020) argues for a new "paradigm shift" (un changement de paradigme) in the way in which we have been analyzing the global crises afflicting our planet and the way in which we have been imagining alternatives (p. 26). He urges the world to change its "path" (changeons de voie). He urges a new green deal, which should be at the same time a new ecological, socioeconomic, and political contract (Morin 2020, p. 55). All the authors reviewed in this essay agree that the pandemic is merely a "rehearsal" (Latour quoted by Žižek 2020, p. 111) of the forthcoming climate catastrophe and other catastrophes including the end of democracies (Attali 2020, p. 190).

One might even say that a new form of selfhood is already emerging, one that thinks only in terms of crises and future catastrophes. Gone is the time of blind faith in science and progress, and gone also is the prospect of what Kant called the "Kingdom of Ends," a "virtual polity of moral aspiration that unites all rational beings" (Nussbaum, 2019). If anything, Kant's Kingdom of Ends now looks Kafkaesque, a world of irrationality, and of 'barbarism,' where the survival of the species rather than democracy and solidarity would prevail. The future looks indeed very bleak. Žižek (2020) is unequivocal: "there is no return to normal, the new 'normal' will have to be constructed on the ruins of our old lives, or we will find ourselves in a new barbarism whose signs are already clearly discernible" (p. 3).

Perhaps the only light at the end of the long tunnel is that everything will have to be reinvented. We need more "resilient" health systems (Horton 2020, pp. 82-88; Attali 2020, pp. 150-153), we need to prioritize health over profit, and we need to treat better and invest more in prevention and preparedness. Attali calls for "a combative form of democracy" (une démocratie de combat) that cares about and invests in the future as well as the unborn generations. Above all, we need to reinvigorate the "spirit" (l'esprit) whose lack in the age of industrial capitalism Karl Marx deplored and which Nancy (2020) argues is what is at stake in this pandemic (p. 33). He writes, "We are henceforth not only without spirit but perhaps even without other body than our 'machinic,' energetic, cathodic and plasma connections" (Nancy 2020, p. 44). "Techno-capitalism" has emptied our souls of any meaning, Nancy (2020) deplores (p. 75). This is why he calls for a renewal of our values and our way of inhabiting this world: "We must relearn how to breathe and how to live, 
quite simply. [...] Let's be children. Let's recreate a language. Let us have this courage" (Nancy 2020, p. 33). Instead of 'happiness,' 'welfare,' and 'prosperity' all captured in one Greek word, eudaemonia, and which until recently was the horizon of a content civilization, it is now the politics of life itself that will define the future and perhaps even become its very raison d'être.

I would even go further. What we need are new conceptual tools to make sense of how democracies are reacting to the pandemic. It is true, as Agamben (2020) says, that the threat of the 'state of exception' taking over still lingers (we saw it playing out in many countries, some overtly authoritarian and some more democratic), but such arguments today sound trite and passé. What we need are new ways of rethinking our modes of production, socioeconomic priorities, and modes of consumption. Imagination and critical thinking will be more than ever vital in reimagining our post-pandemic future. In such a renewed intellectual process and a pressing search for new social contracts, " $\ldots$ the analysis of the forms of madness will be much more important than that of national accounts, and science fiction will be more useful than economics textbooks" (Attali 2020, p. 177).

This is precisely why I think that neither Agamben's alarmism nor Žižek's communitarian rehashing are at all adequate to deal with the post-Covid future. We will need to think outside the box to "look for paths of light and darkness in unexpected places" (Attali 2020, p. 177). The time for new social theories has finally come.

\section{References}

Agamben, G. (2020). The state of exception provoked by an unmotivated emergency. Positions, 26 February, http://positionspolitics.org/giorgio-agamben-the-state-of-exception-provoked-by-an-unmotivate d-emergency/, accessed 29 September 2020.

Archyde. (2020). Roselyne Bachelot, rehabilitation. 26 March, https://www.archyde.com/roselyne-bache lot-rehabilitation/, accessed 1 October 2020.

Brandt, A. M. and Botelho, A. (2020). Not a Perfect Storm-Covid-19 and the Importance of Language. New England Journal of Medicine 382 (16): 1493-1495.

Camus, A. (2002). The Plague. London: Penguin Modern Classics.

Caomhánach, N. and Catlin, J. (2020). Pandemic history and usable pasts. Journal of the History of Ideas (blog), proceedings of the virtual Conference on Pandemic, Creating a Usable Past: Epidemic History, COVID-19, and the Future of Health; 8-9 May 2020: American Association for the History of Medicine and Princeton University's Department of History, https://jhiblog.org/2020/05/27/confe rence-report-pandemic-history-and-usable-pasts/, accessed 30 November 2020.

Cyranoski, D. (2020). The biggest mystery: what it will take to trace the coronavirus source. Nature. https ://doi.org/10.1038/d41586-020-01541-z.

Davey, M. (2020). Covid-19 study on hydroxychloroquine use questioned by 120 researchers and medical professionals. The Guardian, 29 May: https://www.theguardian.com/world/2020/may/29/covid-19surgisphere-hydroxychloroquine-study-lancet-coronavirus-who-questioned-by-researchers-medic al-professionals.

Economist. (2020). EU leaders agree on a massive, €750bn Covid-19 recovery deal. 21 July, https:// www.economist.com/europe/2020/07/21/eu-leaders-agree-on-a-massive-eu750bn-covid-19-recov ery-deal.

Fassin, D. (2018). La vie : Mode d'emploi critique. Paris: Seuil.

Foucault, M. (2004). Naissance de la biopolitique : Cours au Collège de France (1978-1979). Ewald, F., Fontana, A. and Senellart, M. (eds.). Paris: Gallimard. 
Gaspar, V., Medas, P., Ralyea, J. and Ture, E. (2020). Fiscal policy for an unprecedented crisis. International Monetary Fund (blog), 14 October, https://blogs.imf.org/2020/10/14/fiscal-policy-for-anunprecedented-crisis/, accessed 2 November 2020.

Hacking, I. (1982). Biopower and the avalanche of printed numbers. Humanities in Society 5: 279-295.

Harford, T. (2020). Statistics, lies and the virus: Tim Harford's five lessons from a pandemic. Financial Times, 10 September: https://www.ft.com/content/92f64ea9-3378-4ffe-9fff-318ed8e3245e.

Hecketsweiler, C. and de Royer, S. (2020). Les stocks stratégiques de médicaments de la France étaient au plus bas au début de l'épidémie de Covid-19. Le Monde, 24 Septembre: https://www.lemonde.fr/ politique/article/2020/09/24/medicaments-les-stocks-strategiques-en-france-au-plus-bas-au-debut -de-1-epidemie-de-covid-19_6053484_823448.html.

Klein, N. (2008). The Shock Doctrine: The Rise of Disaster Capitalism. London: Penguin.

Latour, B. (1999). Pandora's Hope: Essays on the Reality of Science Studies. Cambridge, MA: Harvard University Press.

Lazarus, J. V., Binagwaho, A., El-Mohandes, A. A. E., Fielding, J. E., Larson, H. J., Plasència, A., Andriukaitis, V. and Ratzan, S. C. (2020). Keeping Governments Accountable: The COVID-19 Assessment Scorecard (COVID-SCORE). Nature Medicine 26 (7): 1005-1008.

Mancini, D. P., Kuchler, H. and Peel, M. (2020). Remdesivir: the rise and fall of a Covid wonder drug. Financial Times, 24 November: https://www.ft.com/content/3be91aa6-0700-4ca8-8ab8-491b6d35e4 fe.

Maxmen, A. (2020). Why the United States is having a coronavirus data crisis. Nature 585 (7823): 13-14.

Mucchielli, L. (2020). Behind the French controversy over the medical treatment of Covid-19: the role of the drug industry. Journal of Sociology, June 17, 2020. https://doi.org/10.1177/1440783320936740

Nussbaum, M. (2019). The Cosmopolitan Tradition: A Noble but Flawed Ideal. Cambridge, MA: Belknap Press of Harvard University Press.

Podcast. (2020). Grippe de Hongkong en 1968: pourquoi on l'a tous oubliée. Le Monde, 9 May: https ://www.lemonde.fr/podcasts/article/2020/05/09/grippe-de-hongkong-en-1968-pourquoi-on-1-a-tousoubliee_6039185_5463015.html.

Reverchon, A. (2020). La crise du coronavirus signale l'accélération d'un nouveau capitalisme, le capitalisme numérique. Le Monde, 2 April: https://www.lemonde.fr/idees/article/2020/04/02/danie 1-cohen-la-crise-du-coronavirus-signale-l-acceleration-d-un-nouveau-capitalisme-le-capitalism e-numerique_6035238_3232.html.

Ricoeur, P. (1999). Memory and Forgetting. In: R. Kearney and M. Dooley (eds.) Questioning Ethics Contemporary Debates in Philosophy. New York: Routledge, pp. 5-11.

Roussel, Y. and Raoult, D. (2020). Influence of conflicts of interest on public positions in the COVID-19 era, the case of Gilead Sciences, New Microbes and New Infections, November 2020, https://doi. org/10.1016/j.nmni.2020.100710.

Sardier, T. (2020). Bruno Latour : 'Face à la crise écologique, nous avons fait exactement ce qu'il ne faut pas faire'. Libération, 13 May: https://www.liberation.fr/debats/2020/05/13/face-a-la-crise-ecolo gique-nous-avons-fait-exactement-ce-qu-il-ne-faut-pas-faire_1788277.

Sayare, S. (2020). He was a science star. Then he promoted a questionable cure for Covid-19. The New York Times, 21 May: https://www.nytimes.com/2020/05/12/magazine/didier-raoult-hydroxychl oroquine.html.

Solis, M. (2020). Naomi Klein on Coronavirus and Disaster Capitalism. VICE, 13 March, https://www. vice.com/en/article/5dmqyk/naomi-klein-interview-on-coronavirus-and-disaster-capitalism-shock -doctrine, accessed 20 November 2020.

Willsher, K., Holmes, O., McKernan, B. and Tondo, L. (2020). US hijacking mask shipments in rush for coronavirus protection. The Guardian, 3 April: https://www.theguardian.com/world/2020/apr/02/ global-battle-coronavirus-equipment-masks-tests.

Publisher's Note Springer Nature remains neutral with regard to jurisdictional claims in published maps and institutional affiliations.

Joelle M. Abi-Rached is an associate researcher at Sciences Po, Paris, France. With Nikolas Rose, she is the author of Neuro: The New Brain Sciences and the Management of the Mind (Princeton University Press, 2013). Her new book is Asfuriyyeh: A History of Madness, Modernity, and War in the Middle East (MIT Press, 2020). 